ZOOLOGIA 32 (4): 296-305, August 2015

http://dx.doi.org/10.1590/S1984-46702015000400005

\title{
Morphological, histological and histochemical analysis of the digestive tract of Trachelyopterus striatulus (Siluriformes: Auchenipteridae)
}

\author{
Marcella L. dos Santos ${ }^{1}$, Fábio P. Arantes¹, Tiago C. Pessali² \& José E. dos Santos ${ }^{1, *}$ \\ 'Programa de Pós Graduação em Zoologia de Vertebrados, Pontifícia Universidade Católica de Minas Gerais. Avenida Dom \\ José Gaspar 500, Coração Eucarístico, 30535-610 Belo Horizonte, MG, Brazil. \\ 2Laboratório de Ictiologia, Museu de Ciências Naturais, Pontifícia Universidade Católica de Minas Gerais. Coração Eucarístico, \\ 30535-610 Belo Horizonte, MG, Brazil. \\ *Corresponding author. E-mail: enemir@pucminas.br
}

\begin{abstract}
The digestive tract of Trachelyopterus striatulus (Steindachner, 1877) was studied using morphological, histological, and histochemical techniques. The barbels, lips and tongue had stratified squamous epithelium with mucous, claviform cells, and taste buds. Trachelyopterus striatulus had a dental plaque with villiform teeth. The bucopharyngeal cavity was formed by the gill apparatus and pharyngeal teeth with vilifform denticles. The oesophagus presented stratified squamous epithelium with mucous cells and taste buds. The stomach included cardiac, fundic, and pyloric regions and a simple prismatic epithelium with prismatic cells that reacted positively to periodic acid-Schiff (PAS) and amylase+PAS. Only the cardiac and pyloric regions responded positively to alcian blue $\mathrm{pH} 2.5(\mathrm{Ab} \mathrm{pH} \mathrm{2.5)} \mathrm{and} \mathrm{alcian}$ blue $\mathrm{pH} 0.5$ ( $\mathrm{Ab} \mathrm{pH} \mathrm{0.5).} \mathrm{The} \mathrm{cardiac} \mathrm{and} \mathrm{fundic} \mathrm{regions} \mathrm{exhibited} \mathrm{tubular} \mathrm{gastric} \mathrm{glands.} \mathrm{The} \mathrm{intestine} \mathrm{was} 118.90 \pm$ $22.49 \mathrm{~mm}$ long with an intestinal coefficient $(\mathrm{CO})$ of $0.83 \pm 0.13$. The epithelium was simple prismatic with a brush border and goblet cells, and a greater number of goblet cells were found in the caudal region of the intestine. The mucous cells and goblet cells reacted positively to PAS, amylase+PAS, $\mathrm{Ab} \mathrm{pH} 2.5$, and $\mathrm{Ab} \mathrm{pH} 0.5$. We analysed if the function of the mucosubstances and morphological characteristics of the digestive tract of $T$. striatulus are compatible with omnivorous feeding habit.
\end{abstract}

KEY WORDS. Anatomy; catfish; morphology; mucosubstances; omnivorous.

The anatomy and histology of the barbels, oral and bucopharyngeal cavities, teeth, oesophagus, stomach and intestine of a number of fish species have been studied by SINGH \& Kapoor (1967), Agrawal \& Mittal (1992), Rodrigues \& Menin (2006a), Hernández et al. (2009), and Abbate et al. (2012). According to Cinar \& SENOL (2006), the digestive tracts of fish have notable differences in form and function, thereby emphasising the need for more studies of this type. Anatomical, histological, and histochemical studies provide information for the characterisation of the digestive tract, thus enabling the understanding of the physiology, feeding habits, and management of fish species (Vegas-Velez 1972, Rodrigues \& Menin 2005, Germano et al. 2014).

The barbel structures as well as the oral and bucopharyngeal cavities play important roles in identifying, selecting, capturing, and grasping food (AL-HussaINI 1946, SinGH \& KAPOOR 1967, Rodrigues \& Menin 2006a, b). The oesophagus, stomach, and intestine are responsible for transport, storage, digestion, and absorption of nutrients (Albrecht et al. 2001, Xiong et al. 2011). The presence of mucosubstances in the epithelium of the digestive tract of fish has also been the subject matter of many studies due to their roles of humidifying the epithelium, altering viscosity, protecting against pathogens, food handling, and guiding
(Petrinec et al. 2005, Cao \& Wang 2009, Yashpal \& Mittal 2014). The catfish Trachelyopterus striatulus (Steindachner, 1877), popularly known as "cangati" or "cumbaca", is an Auchenipteridae that is present in some coastal rivers of south-eastern Brazil (ReIs et al. 2003). Studies on the diet of T. striatulus were performed by Dias et al. (2005), who identified them as omnivorous but tending towards insectivory. SANTOS et al. (2009) also refered to the species as a bio-indicator of water quality in Neotropical reservoirs.

However, there are no studies on the morphology of the digestive tract of this species, or studies that analyse, all organs involved in perception, ingestion, digestion and absorption. In this sense, our study describes the morphology of the digestive tract of T. striatulus using anatomical, histological, and histochemical techniques.

\section{MATERIAL AND METHODS}

Sixty-two specimens of $T$. striatulus of both sexes were collected from the Doce River (18 $\left.59^{\prime} 37^{\prime \prime} \mathrm{S} 42^{\circ} 13^{\prime} 33^{\prime \prime} \mathrm{W}\right)$, southeastern Brazil, from November 2009 to December 2010. Sampling was conducted using gillnets with mesh sizes of 3 to $8 \mathrm{~cm}$ 
between opposite knots. Forty-eight specimens were fixed in $10 \%$ formalin for 12 hours and transferred to $70 \%$ ethanol, which were then used for anatomical study. Fragments from different regions of the digestive tract of ten other specimens were taken for histological study and statistical analysis. The remaining four specimens were prepared and deposited in the fish collection of the PUC Minas Science Museum under numbers MCNIP 0195 and MCNIP 0464. The handling of the specimens followed the guidelines of the National Council for the Control of Animal Experimentation (CONCEA) for euthanizing animals (BRASIL 2013), and the fish collection was authorised by the State Forest Institute of Minas Gerais (IEF - licenses 107-09, 164-10).

For each specimen, the standard length (SL; cm) and body weight $(\mathrm{g})$ were recorded. The digestive tract was dissected, and the length $(\mathrm{mm})$ of the barbels, oral slit, and intestine $(\mathrm{CI}$; $\mathrm{mm}$ ) were measured. Subsequently, the intestinal coefficient (CO) was calculated using the equation: $\mathrm{CO}=\mathrm{CI} / \mathrm{SL}$, according to ANGelescu \& GNeRI (1949). In order to check the adaptations of the oral cavity related to food identification, capture, and seizing, the following were described: the barbels, the shape of the lips and tongue, the morphology of the pharyngeal teeth, and the type of pharyngeal teeth apparatus. The barbels and oral slit from the digestive tract were measured using digital callipers (DIGIMESS - accuracy of $0.01 \mathrm{~mm}$ ). To measure the intestines, a tape measure (MACROLIFE) was used to measure length and flexure. The results are given as mean and standard deviation $(\mathrm{M} \pm \mathrm{SD})$. All structures were analysed using a stereomicroscope Olympus SZ-11.

Fragments of the barbels, lips, tongue, oesophagus, stomach (cardiac, fundic, and pyloric regions), intestine (cranial, middle, and caudal sections) were fixed in Bouin's fluid for six hours and subsequently subjected to histological techniques with haematoxylin-eosin (HE) and Masson's trichrome (TG) stains. Some sections were processed for carbohydrate and protein analysis, following PeArse (1985): periodic acid-Schiff (PAS) for carbohydrates with 1:2 glycol groups; glycogen, neutral glycoproteins and sialomucin; salivary amylase $\left(30 \mathrm{~min}\right.$ at $\left.37^{\circ} \mathrm{C}\right)$ for glycogen digestion, followed by PAS (amylase + PAS), performing the counter test with rat intestine; alcian blue $\mathrm{pH} 2.5$ $(\mathrm{Ab} \mathrm{pH} 2.5)$ for carboxylated and sulphated glycoconjugate acids including sialomucines, alcian blue pH 0.5 (Ab pH 0.5) to sulphated glycoconjugates.

The number of goblet cells in a $200 \mu \mathrm{m}$ length from the mucosa folds of the cranial, middle, and caudal intestine, extending up to the villi, was determined. Ten slides from each region were made, and twenty random measurement replicates from each slide were taken. The results referring to the number of goblet cells are given as mean and standard deviation $(\mathrm{M} \pm \mathrm{SD})$. The measurements were performed using the free Image J software from scanned images.

In order to determine whether there were differences in the number of goblet cells from the three intestinal regions, we used the arithmetic mean of the measurement replicates, according to JaroszewsKa et al. (2008). Appropriate statistical analysis was conducted using the Lilliefors test of normality. Data with normal distribution were compared using analysis of variance for a randomised block design (RBD ANOVA), where the blocks were the individuals and the treatment was the intestinal regions. Post-hoc (Tukey) tests were performed when the ANOVA indicated a significant difference between treatments or between blocks in order to detect the difference between the means. All analyses were performed using the BioStat 5.0 package $(\mathrm{p}<0.05)$.

\section{RESULTS}

\section{Anatomy and morphometry}

The specimens presented a standard length of $14.13 \pm 1.09$ $\mathrm{cm}$ and body weight of $77.92 \pm 16.81 \mathrm{~g}$. Trachelyopterus striatulus had a pair of maxillary barbels that were $36.82 \pm 4.74 \mathrm{~mm}$ long and two mentonian pairs, a medial one measuring $11.45 \mathrm{~mm} \pm$ 2.75 and a lateral one measuring $25.36 \pm 3.59 \mathrm{~mm}$. The oral cavity is bounded anteriorly by the upper and lower lips and caudally by the first gill arch (Figs. 1,2). The mouth is terminal, presenting a $17.31 \pm 2.22 \mathrm{~mm}$ long oral slit. The lips are thin, the upper lip being attached to the maxilla and pre-maxilla and the lower one to the mandible. The dental plaque consists of villiform teeth (Figs. 1, 2). The tongue rests on the floor of the oral cavity and has a rounded apex (Fig. 1). The bucopharyngeal cavity is formed by the gill and pharyngeal teeth apparatus (Figs. $1,2)$. The branchial apparatus consists of five pairs of gill arches. The gill arches I, II, III, and IV have two segments, ventral and dorsal, while gill arch $\mathrm{V}$ presents only the ventral segment (Figs. 1,2 ). The pharyngeal teeth are located in the caudal portion of the bucopharyngeal cavity and consist of two ventral kidneyshaped dental plates and two dorsal oval ones, both with villiform denticles (Figs. 1, 2). The oesophagus is a tubular organ with longitudinally pleated mucosa that connects the bucopharyngeal cavity to the stomach (Fig. 3). The stomach has a "C" shape with three regions: cardiac, fundic, and pyloric (Fig. 3). The intestine was $118.90 \pm 22.49 \mathrm{~mm}$ long with an intestinal coefficient of $0.83 \pm 0.13$. The cranial intestine is formed by the pyloric flexure, which is ventral to the oesophagus and follows a downward loop, attached to the mid region of the right side of the stomach. The mid-intestine runs through the caudal portion of the right side of the stomach up to the downward flexure. The caudal intestine is linear and it is medially located in the coelomic cavity, extending to the anal opening (Fig. 3). Trachelyopterus striatulus showed no pyloric caeca.

\section{Histology}

Barbels and oral cavity. Microscopically, the barbels, lips, and tongue presented a stratified squamous epithelium, with taste buds as well as mucous and claviform cells (Figs. 4, $5,8,11)$. The mucous cells showed a basal nucleus and mucusfilled cytoplasm. The claviform cells showed a central nucleus 

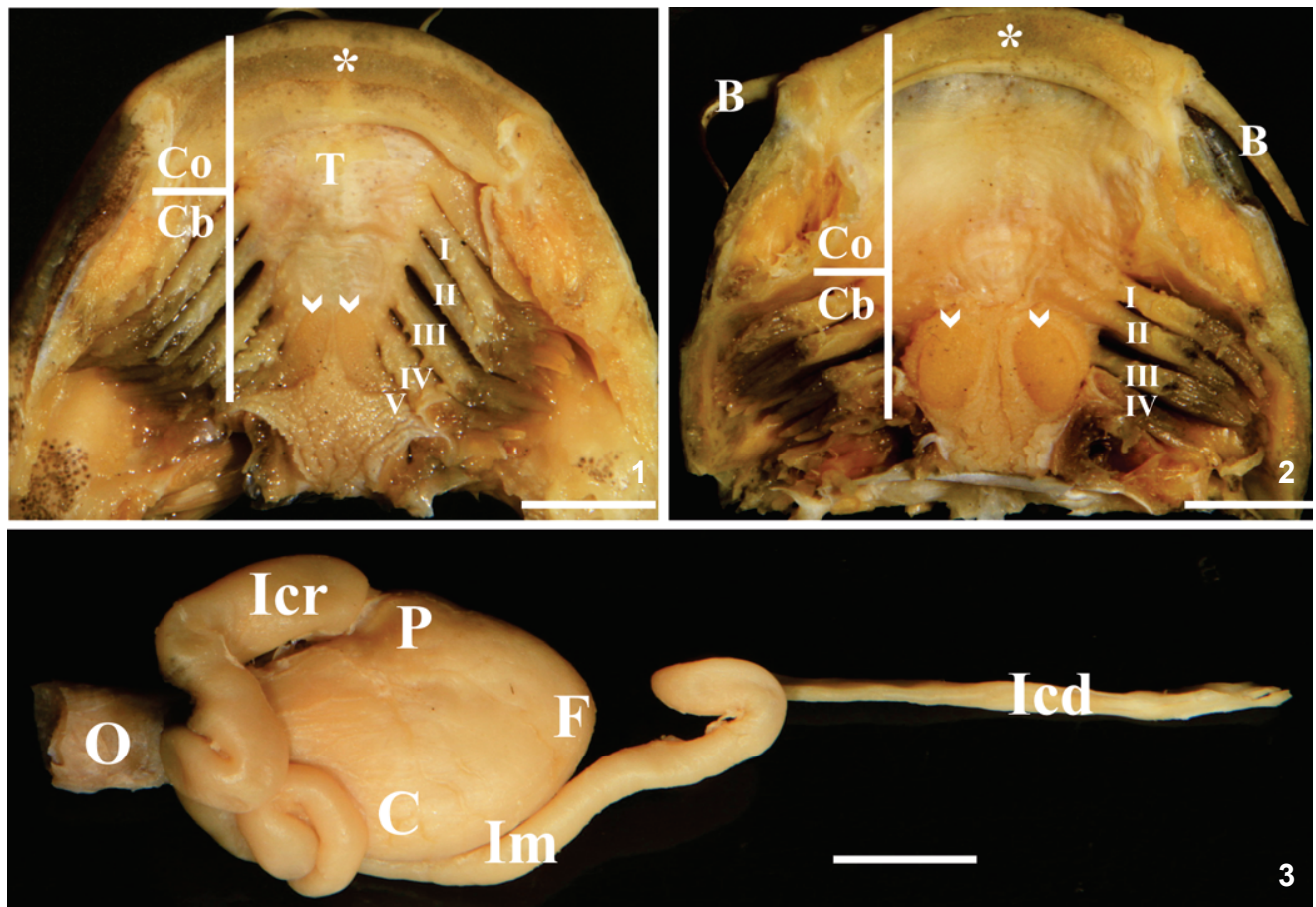

Figures 1-3. Structures of the digestive tract of T. striatulus. (1). Floor of the oral cavity (Co), bucopharyngeal cavity (Cb), showing: dental plaque (asterisk), tongue ( $\mathrm{T}$ ), pharyngeal teeth apparatus (arrowhead), branchial arches (I to V), (bar = $1 \mathrm{~cm}$ ). (2) Oral cavity roof (Co), bucopharyngeal (Cb) showing: barbels (B), dental plaque (asterisk), branchial arches (I to IV), pharyngeal teeth apparatus (arrowhead), (bar $=1 \mathrm{~cm})$. White bar indicates the boundary between the oral and the bucopharyngeal cavities. (3). Ventral view of structures of the digestive tract, showing: oesophagus $(\mathrm{O})$, cardiac $(\mathrm{C})$, fundic $(\mathrm{F})$, pyloric $(\mathrm{P})$ regions, cranial intestine (Icr), midintestine (Im), caudal intestine $(\mathrm{lcd})$, (bar $=1 \mathrm{~cm})$.

and acidophilic cytoplasm. The taste buds are scattered at the apex of the epithelium and are supported by the dermis.

Oesophagus. Microscopically, the oesophagus consists of the following layers: mucosa, submucosa, muscularis, and serosa (Fig. 14). The epithelium is stratified squamous with epithelial cells interspersed with mucous cells and taste buds (Fig. 15). The submucosa layer consists of dense connective tissue and blood vessels. The muscular layers are limited by loose connective tissue and present striated muscular fibres arranged longitudinally on the inner sub-layer and in a circular shape on the outer sub-layer. The serosa layer is the outermost and consists of dense connective tissue and mesothelium. The transition from the oesophagus to the stomach was accompanied by the replacement of the stratified squamous epithelium with mucous cells to a simple prismatic epithelium with gastric glands (Fig. 19).

Stomach. Microscopically, the three regions of the stomach have mucosa, submucosa, muscularis, and serosa layers (Figs. $20,21)$. The epithelium is prismatic with cells exhibiting an oval nucleus and acidophilic cytoplasm. The gastric glands are tubular, with oxynthic and peptic cells, supported on the lamina propria, they were observed only in the cardiac (Fig. 20) and fundic regions but not in the pyloric region (Fig. 21). The submucosa layer consists of dense connective tissue and blood vessels. The muscular layer consists of two sub-layers: an internal one, with smooth muscle fibres oriented in a circular arrangement, and an external one, with longitudinal smooth muscle fibres, both interspersed with loose connective tissue. The serosa layer presented loose connective tissue and mesothelium.

Intestine. The three regions of the intestine showed structural organisation, consisting of the mucosa, submucosa, muscularis, and serosa layers (Figs. 27-29). The epithelium is a simple prismatic one, with brush border and prismatic cells showing an elongated nucleus and acidophilic cytoplasm, intermingled with goblet cells (Fig. 30). The cranial (10.27 \pm 1.26$)$ and medium $(19.19 \pm 1.24)$ regions of the intestine showed significantly lower number of goblet cells than the caudal region $(25.68 \pm 2.70)(\mathrm{p}<0.05)$. The submucosa layer presented loose connective tissue and blood vessels, which follow the folds of the mucosa. The muscular layer consisted of smooth muscle tissue with fibres circumferentially oriented in the internal sub-layer, and longitudinally on the external one, and both showed loose connective tissue. The serosa layer exhibited loose connective tissue and mesothelium. 


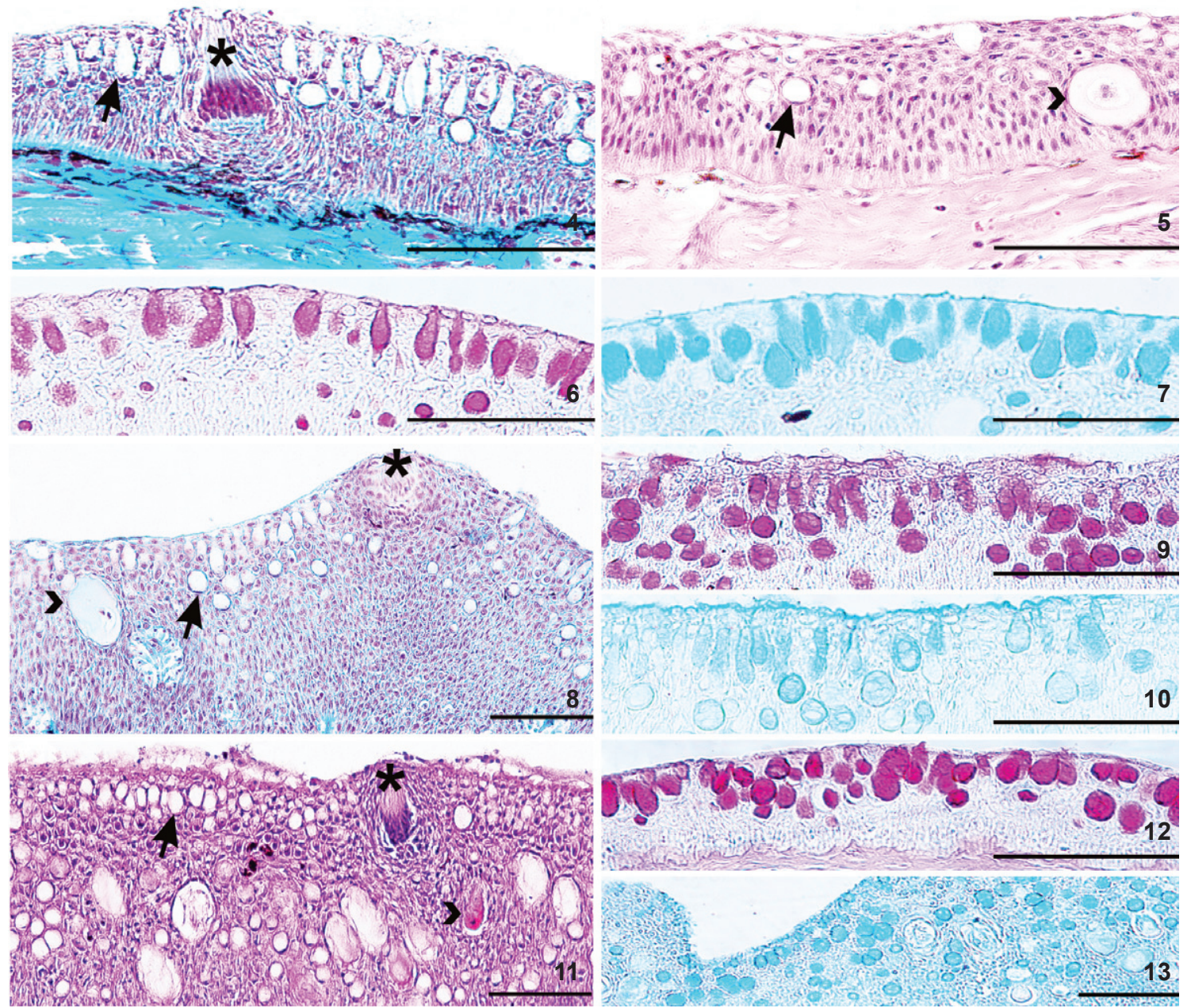

Figures 4-13. Structures of the digestive tract of $T$. striatulus. (4) Cross section of the maxillary barbel showing: taste bud (asterisk) and mucosal cell (arrow), TG, (bar $=100 \mu \mathrm{m})$. (5) Longitudinal section of the mentonian barbel showing: claviform cells (arrowheads) and mucosal cell (arrow), HE, (bar $=100 \mu \mathrm{m})$. (6) Positive reaction to PAS of the mucosa cell of the maxillary barbel, $($ bar $=100 \mu \mathrm{m})$. $(7)$. Positive reaction to $\mathrm{Ab} \mathrm{pH} 2.5$ of the mucosa cell of the maxillary barbel, (bar $=100 \mu \mathrm{m})$. (8) Longitudinal section upper lip showing: taste buds (asterisk), mucosal cell (arrow), claviform cells (arrowheads), TG, (bar $=100 \mu \mathrm{m})$. (9) Positive reaction to PAS of the mucosa cell present in the upper lip, (bar $=100 \mu \mathrm{m})$. (10) Positive reaction to $\mathrm{Ab} \mathrm{pH} 0.5$ of the mucosa cell present in the upper lip, (bar $=100 \mu \mathrm{m})$. (11) Cross section of the tongue showing: taste bud (asterisk), mucosa cell (arrow), claviform cells (arrowheads), HE, (bar = $100 \mu m) .(12)$ Positive reaction to PAS of the mucosa cell present in tongue, (bar $=100 \mu \mathrm{m})$. (13) Positive reaction to Ab pH 2.5 of the mucosa cell present in tongue, $($ bar $=100 \mu \mathrm{m})$.

\section{Histochemistry}

The mucous and goblet cells reacted positively to PAS, amylase + PAS, $\mathrm{Ab} \mathrm{pH} \mathrm{2.5,} \mathrm{and} \mathrm{Ab} \mathrm{pH} 0.5$, indicating neutral glycoproteins and acid glycoconjugate sulphates and carboxylated (Figs. 6, 7, 9, 10, 12, 13, 16-18, 31-33). The prismatic cells of the stomach reacted positively to both PAS and amylase + PAS, showing the presence of neutral glycoproteins (Figs. 2224), while only the prismatic cells of the cardiac and pyloric regions positively reacted to $\mathrm{Ab} \mathrm{pH} 2.5$ and $\mathrm{Ab} \mathrm{pH} 0.5$, indicat- ing the presence of carboxylated and sulphated glycoconjugate acids (Figs. 25, 26).

\section{DISCUSSION}

Morphological analyses of the digestive tract are essential to understand the biology of species, physiology, fish management, and conservation, as seen in important studies such as those by Rodrigues \& Menin (2005), Xiong et al. (2011), and Germano et al. (2014). 


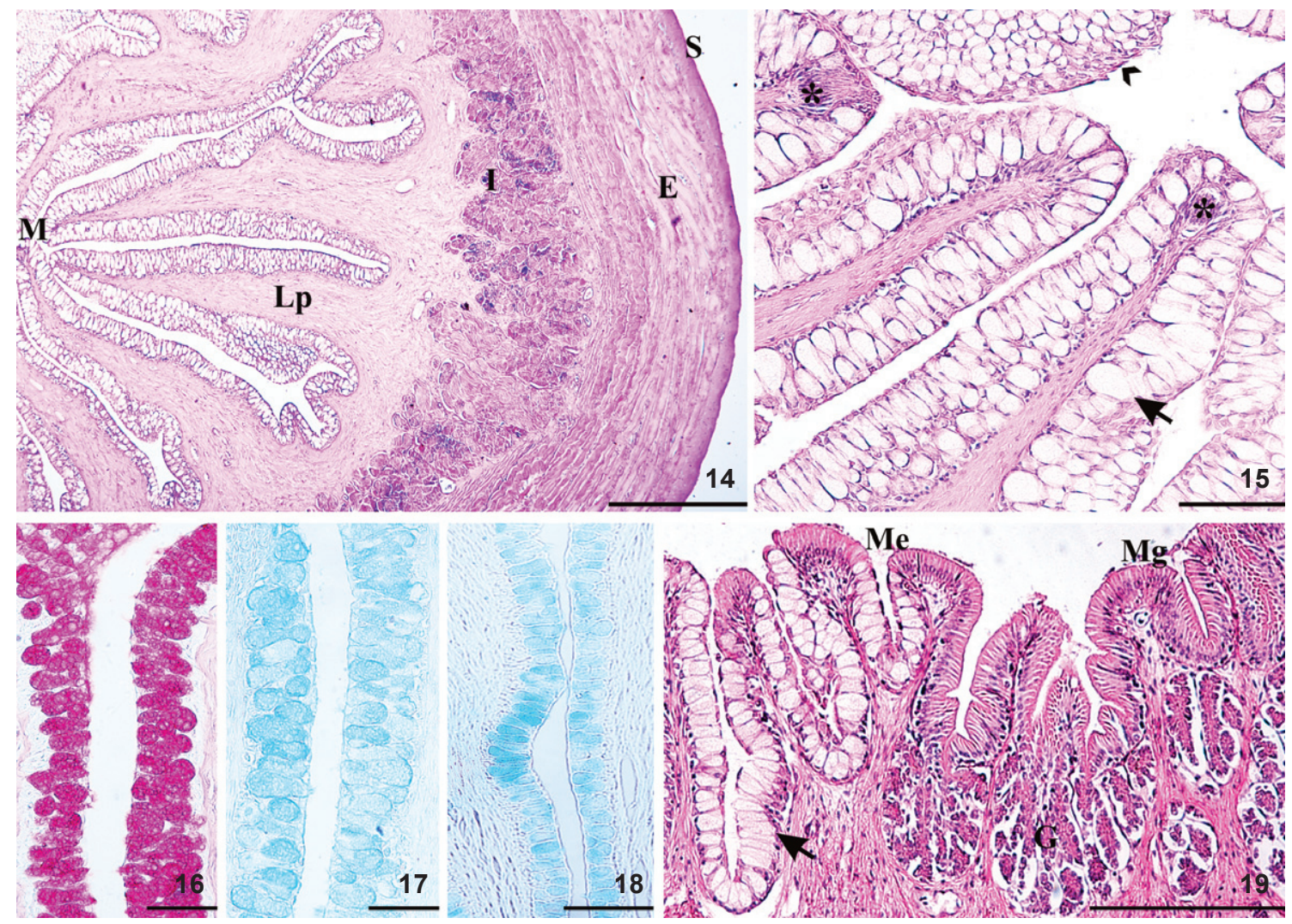

Figures 14-19. Histological organization of the oesophagus of T. Striatulus. (14) Cross section showing mucosa (M), lamina propria (Lp), internal muscular layer (I), external muscular layer (E), serosa $(S), H E,(b a r=500 \mu m) .(15)$ Mucosa detail showing: taste bud (asterisk), mucosa cell (arrow), epithelial cells (arrowhead), HE, (bar $=100 \mu \mathrm{m})$. (16) Positive reaction to PAS of the mucosa cell present in the oesophagus, $(\mathrm{bar}=100 \mu \mathrm{m})$. (17) Positive reaction to $\mathrm{Ab} \mathrm{pH} 2.5$ of the mucosa cell present in the oesophagus, $($ bar $=100 \mu \mathrm{m})$. $(18)$ Positive reaction to $\mathrm{Ab} \mathrm{pH} 0.5$ of the mucosa cell present in the oesophagus, (bar $=300 \mu \mathrm{m})$. (19) Longitudinal section of the transition from the oesophagus to stomach, showing: stratified squamous epithelium (Me), mucous cells (arrow), simple prismatic epithelium $(\mathrm{Mg})$ gastric glands $(\mathrm{G}), \mathrm{HE},($ bar $=200 \mu \mathrm{m})$.

Some fish species have barbels with sensory structures, such as mechanoreceptors and chemoreceptors, which can be adapted to benthic life (Godinho 1967, Kapoor \& BHargava 1967, PARK et al. 2012). In this study, we described the barbels of $T$. striatulus, as previously recorded in species of Siluriformes, such as Pimelodus maculatus (Lacépède, 1803) (Godinho 1967), Pseudoplatystoma corruscans (Spix \& Agassiz, 1829) (RoDrigues \& Menin 2006a), and Conorhynchos conirostris (Valenciennes, 1984) (Rodrigues \& Menin 2005). Specimens of $P$. maculatus, $P$. corruscans, and T. striatulus have long barbels, as noted by Rodrigues \& Menin (2006a, b) and also observed in this study, whereas specimens of $C$. conirostris presented short barbels as described by Rodrigues \& Menin (2005).

Histologically, the presence of mucous, claviform cells, and taste buds found in the barbels of $T$. striatulus suggests that the released mucus would facilitate their movement in the water column, decreasing drag. The claviform cells protect from injury (GoDINHo et al. 1970) and the taste buds identify food (SINGH \& KAPOOR 1967). Histochemical analysis of mucous cells indicated the presence of neutral mucus, sulphated and carboxylated acids, which probably contribute to mechanical protection against bacterial invasion. In teleosts, the mouth is classified according to its position as dorsal, terminal, sub-terminal, or ventral (NiKolsky 1963) and several studies correlate the position to the feeding habits (Rodrigues \& Menin 2006a, b). The mouth of T. striatulus is in the terminal position, as in P. maculatus (Rodrigues \& Menin 2006b), and both species are omnivorous (Rodrigues \& MENIn 2006b, Dias et al. 2005). The potential difference between these species is the size of the oral slit opening. While T. striatulus features a small mouth slit, suggesting an adaptation to ingest smaller pieces of food, $P$. maculatus has a larger opening that enables it to capture and ingest larger prey. This difference between $P$. maculatus and $T$. striatulus is consistent with omnivorous feeding habits that tend 

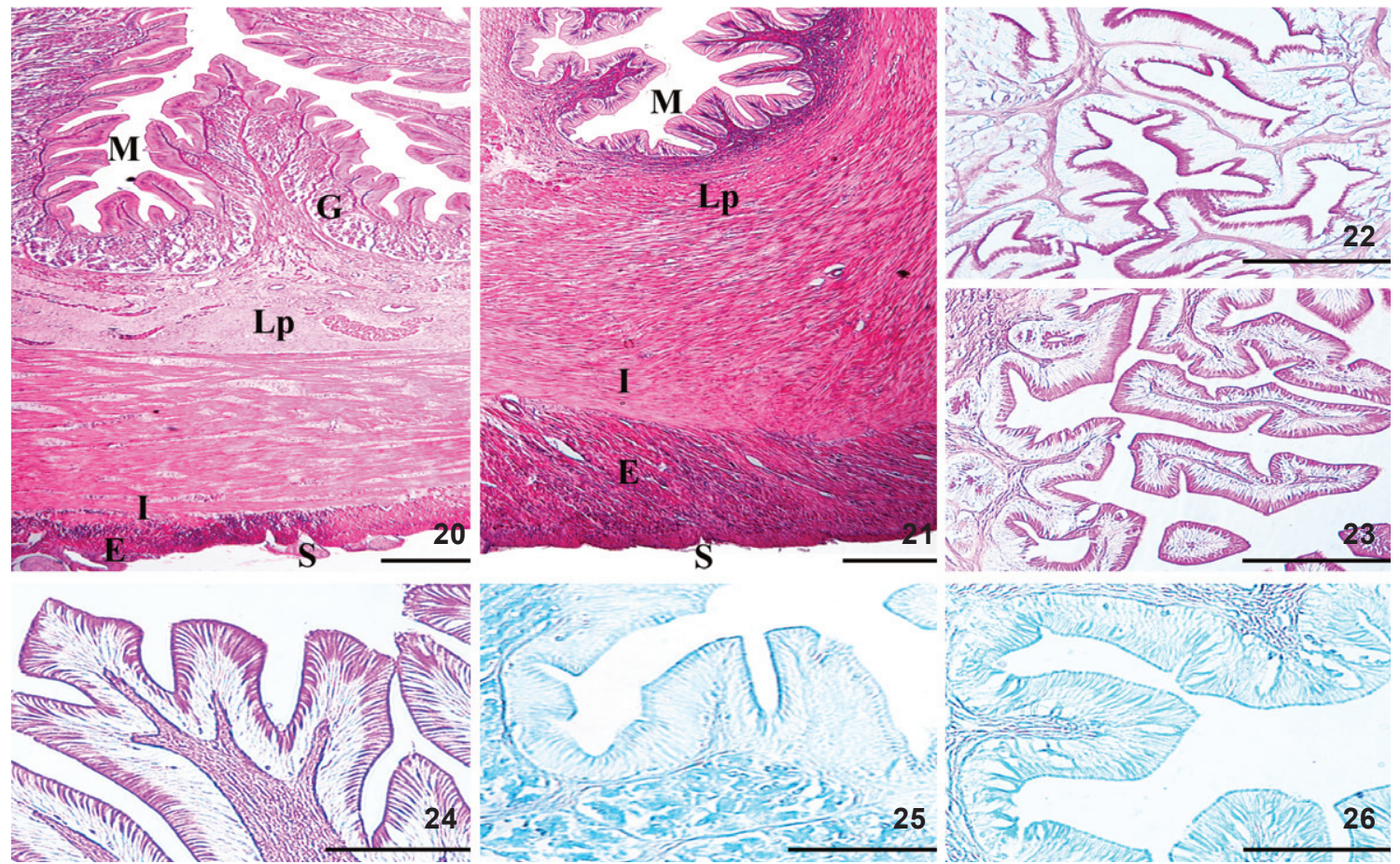

Figures 20-26. Histological organization of the stomach: (20) Cardiac region showing: mucosa (M), gastric glands (G), lamina propria (Lp), internal muscular layer (I), external muscle layer $(E)$, serosa $(S), H E$, (bar $=500 \mu \mathrm{m})$. (21) Pyloric region highlighting the mucosa (M), lamina propria (Lp), internal muscle layer (I), external muscle layer (E), serosa (S), HE, (bar = $500 \mu m)$. (22) Cardiac region showing a positive reaction in the apex of the PAS prismatic cell, $(\mathrm{bar}=200 \mu \mathrm{m})$. (23) Fundic region showing a positive reaction in the apex of the PAS prismatic cell, $(\mathrm{bar}=200 \mu \mathrm{m})$. (24) Pyloric region showing a positive reaction in the apex of the PAS prismatic cell, $($ bar $=100$ $\mu \mathrm{m})$. (25) Cardiac region showing $\mathrm{Ab} \mathrm{pH} 2.5$ - Positive reaction in the prismatic cell apex, (bar $=200 \mu \mathrm{m})$. (26) Pyloric region showing $\mathrm{Ab} \mathrm{pH} 2.5$ - Positive reaction in the prismatic cell apex, (bar $=100 \mu \mathrm{m})$.

to ichthyophagy and insectivorous habits, respectively (DIAs et al. 2005, Rodrigues \& Menin 2006b).

The shape of the lips in different species of fish is related to the feeding habits and to their ecological niches (AgraWAL \& Mittal 1992), and for Khanna \& Mehrotra (1970) and Kapoor et al. (1975), they produce mucus and are primary food detectors. Trachelyopterus striatulus presented a stratified squamous epithelium with taste buds, as observed in Glyptosternum maculatum (Regan, 1905) (XIONG et al. 2011). Histochemical analyses of this study showed neutral mucus, carboxylic and sulphated acids, which, according to Agrawal \& MitTal (1992), are important in labial epithelium lubrication and protection.

According to Al-HussainI (1946), the nature of the diet has a strong correlation with the form and structure of the oral teeth. Trachelyopterus striatulus, which is omnivorous (DiAs et al. 2005), presented villiform teeth and dental plates similar to other species of Siluriformes, such as P. maculatus (GodinHo 1967) and Trichomycterus brasiliensis (Lütken, 1874) (OliveIrARibeiro \& Menin 1996). However, Sorubim trigonocephalus (Miranda Ribeiro, 1920) (Schuingues et al. 2013) is carnivorous and its dentition is similar to T. striatulus, suggesting that the relationship between diet and type of teeth is not fully consistent with the literature on this species. Other analyses, such as stomach contents and morphology of the oral cavity, are needed to determine the feeding habits of the species.

The tongues of fish play little part in swallowing and are instead associated with identification and capture of food (BARRIngton 1957, El BaKary 2011). In T. striatulus, the tongue showed a stratified squamous epithelium with taste buds, as described for the marine species Sparus aurata (Linnaeus, 1758) (Aввате et al. 2012). For T. striatulus, the presence of mucous cells and their positivity to histochemical reactions suggests their importance in the lubrication of the epithelium, thus facilitating the transportation of food.

The bucopharyngeal cavity and pharyngeal teeth present in $T$. striatulus were similar to the Siluriformes $P$. maculatus (Rodrigues \& Menin 2006b), C. conirostris (Rodrigues \& Menin 2005), and S. trigonocephalus (Schuingues et al. 2013). For Horn (1998) and Rodrigues et al. (2006), the shape of the pharyngeal dental plaques and tooth types may indicate the feeding hab- 

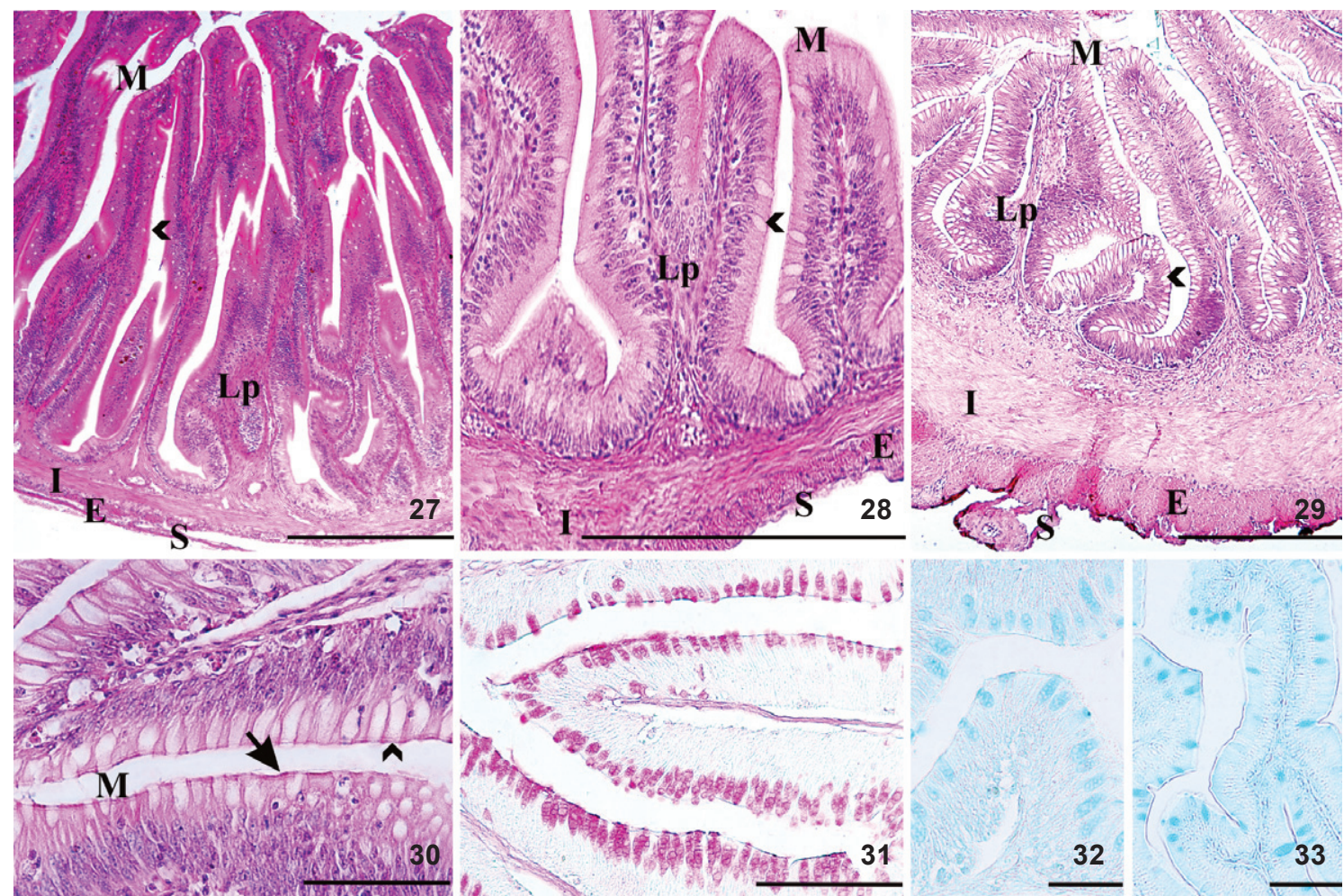

Figures 27-33. Histological organization of the intestine of T. striatulus: (27) Cross section of the cranial intestine, showing: mucosa (M), goblet cells (arrowhead), lamina propria (Lp), internal muscle layer (I), external muscle layer (E), serosa $(S), H E,(b a r=500 \mu m) .(28)$ Cross section of the midintestine, showing: mucosa (M), goblet cells (arrowhead), lamina propria (Lp), internal muscle layer (I), external muscle layer $(E)$, serosa $(S), H E$, (bar $=500 \mu \mathrm{m})$. (29) Cross section of the caudal intestine, showing: mucosa (M), goblet cells (arrowhead), lamina propria (Lp), internal muscle layer (I), external muscle layer (E), serosa (S), HE, (bar $=500 \mu \mathrm{m})$. (30) Detail of the mucosa (M) showing: goblet cell (arrowhead), brush border (arrow), HE, (bar = $100 \mu \mathrm{m})$. (31) PAS - Positive reaction of the intestine goblet cell, $(\mathrm{bar}=200 \mu \mathrm{m})$. (32) Ab pH 2.5 - Positive reaction of the intestine goblet cells, $($ bar $=100 \mu \mathrm{m})$. (33) Ab pH $0.5-\mathrm{Positive}$ reaction of the intestine goblet cells, $($ bar $=100 \mu \mathrm{m})$.

its of the species. We suggest that the presence of villiform teeth in the pharyngeal teeth of T. striatulus is associated with capturing and guiding the food, as described for Leporinus macrocephalus (Garavello \& Britski, 1988) (Rodrigues et al. 2006), which is also omnivorous.

The oesophagus is a short and tubular muscular organ that connects the bucopharyngeal cavity to the stomach (MENIN \& Minura 1993), as observed in T. striatulus. The epithelium described for the species in another study was similar to that of Ictalurus punctatus (Rafinesque, 1818) (Sis et al. 1979), T. brasiliensis (OliveIRA-RIBEIRo \& FANTA 2000), Rhamdia quelen (Quoy \& Gaimard, 1824) (HERnández et al. 2009), and G. maculatum (XIONG et al. 2011). According to Humbert et al. (1984) and Xiong et al. (2011), it is in the epithelial tissue where cell renewal occurs, which is important for mucosal layer maintenance, thus protecting against the invasion of pathogens as well as mechanical injuries. In fact, eating insects like coleopterans, as described for the species under study (Dias et al. 2005), can cause injury to the oesophageal tissue, but the epithelium protects this layer. Mucous cells were observed in the oesophageal epithelium of $T$. striatulus, and they reacted positively to histochemical analysis, similar to P. maculatus (GodinHo et al. 1970) and T. brasiliensis (OlIVEIRA-RIBEIRo \& FANTA 2000), suggesting that this action of the mucus is associated to guiding different types of prey and lubricating the food, also described by OliveIRA-Ribeiro \& FANTA (2000) and XIONG et al. (2011). Taste buds were observed in the oesophageal epithelium of T. striatulus and in the Siluriformes I. punctatus (Sis et al. 1979), T. brasiliensis (OLIVEIRA-RIBEIRo \& FANTA 2000), and G. maculatum (XIONG et al. 2011). Thus, this structure facilitates the identification and selection of food during ingestion. The arrangement of the muscular layers and the striated muscles of the oesophagus of $T$. striatulus were similar to those described for I. punctatus (Sis et al. 1979), P. maculatus (SANTos et al. 2007), and Pelteobagrus fulvidraco (Richardson, 1846) (CAO \& WANG 2009). We suggest that this organisation allows distension of the oesophagus, facilitating food intake. 
In the present study, the stomach exhibited the cardiac, fundic, and pyloric regions in a "C-shape". However, other stomach shapes in Siluriformes have been reported in the literature, such as a "J-shape " in I. punctatus (Sis et al. 1979) and R. quelen (Hernández et al. 2009) as well as a "U-shape " in Pterodoras granulosus (Valenciennes, 1821) (Germano et al. 2014) and $P$. fulvidraco (CAO \& WANG 2009). The stomach of $T$. striatulus presented a simple, prismatic epithelium, similar to species of Siluriformes studied by Sis et al. (1979), HernándeZ et al. (2009), and Xiong et al. (2011). On the other hand, Petrini (1961) observed in the Siluriformes Hypostomus plecostomus (Linnaeus, 1758) a simple squamous epithelium in the cardiac and fundic regions but a simple prismatic epithelium in the pyloric region. Fish may have gastric glands in different regions of the stomach. Rhamdia quelen (Hernández et al. 2009) presented glands in the fundic and pyloric regions, with the cardiac region being aglandular, while in I. punctatus (Sis et al. 1979) and P. granulosus (Germano et al. 2014), the pyloric region was described as aglandular, as was observed in T. striatulus. The presence of neutral, acid, and sulphate mucus in the stomach of $T$. striatulus indicates mucosal protection against chemical agents, maintaining the integrity of the gastric wall and buffering the gastric juices (Morrison \& Wright JR 1999, Petrinec et al. 2005).

Several authors, such as AL-Hussaini (1949), ANGELESCU \& GNERI (1949), and BÉRTIN (1958), correlate intestinal length with feeding habits, and from these reports the morphometric indicator, intestinal coefficient (CO), was described. The values of $\mathrm{CO}$ are different for fish of varying feeding habits. For carnivorous fish, the values are between 0.2 and 2.5, while for omnivorous fish, they range from 0.6 to 8.0 and herbivorous fish have values between 0.8 and 15.0. For T. striatulus, a CO of $0.83 \pm 0.13$ was recorded, compatible with an omnivorous feeding habit. For G. maculatum (carnivorous), the $\mathrm{CO}$ value was 0.89 (XIong et al. 2011), while for R. quelen (omnivorous), it was $0.65 \pm 0.06$ (Hernández et al. 2009). However, assigning values to different feeding habits does not mean that the intestinal coefficient alone cannot determine the feeding habits of the species. Complementing analyses, such as morphological and stomach content analyses, are required. Histologically, the intestine of $T$. striatulus consists of a simple prismatic epithelium with brush border, prismatic and goblet cells, as described for species of Siluriformes studied by Oliveira-Ribeiro \& FAnta (2000), Santos et al. (2007), Hernández et al. (2009), and XIONG et al. (2011). The goblet cells reacted positively to the histochemical techniques employed, indicating the presence of neutral, acid, and sulphate mucus. We suggest that the function of this mucus is associated with the lubrication of the intestinal mucosa and therefore, it facilitates the traffic of macromolecules toward defecation. The cranial, middle, and caudal regions of the intestine of $T$. striatulus showed significant differences in the number of goblet cells, with the caudal region exhibiting higher values. Similar results were also reported for Seriola dumerili (Risso, 1810)(Grau et al. 1992), Solea senegalensis (Kaup, 1858) (ArelLano et al. 2002), and P. granulosus (GERMANo et al. 2014), and the importance of increased mucus production for mucosal protection and lubrication for faecal expulsion was emphasised.

In summary, the anatomical, histological, and histochemical study of the digestive tract of $T$. striatulus showed barbels with gustatory function, oral and pharyngeal villiform dental plates, a simple glandular stomach, short intestine, intestinal coefficient compatible with omnivorous feeding habit, and the production of mucosubstances throughout its length. This study contributes to the understanding of the digestive physiology of the investigated species and provides histological data to be used as a reference for the understanding of biological changes that may affect the digestive tract of fish. Furthermore, they will be useful for comparative analyses within the group, providing input for future evolutionary studies.

\section{ACKNOWLEDGMENTS}

The authors wish to thank CAPES, FAPEMIG and PUC Minas PROBIC for their financial support, Rubens Miranda and Rogério Matos for preparing the histologic slides, and Cássio C. Xavier and Elvira C.A. Horácio, of the PUC Minas Biology Information Treatment Lab, for the help with the photographic documentation.

\section{LITERATURE CITED}

Abbate F, Guerrera MC, Montalbano G, Ciriaco E, Germaná A (2012) Morphology of the tongue dorsal surface of gilthead seabream (Sparus aurata). Microscopy Research and Technique 75(12): 1666-1671. doi: 10.1002/jemt.22114

Agrawal N, Mittal AK (1992) Structure and histochemistry of the epithelia of lips and associated structures of a catfish Rita rita. Japanese Journal of Ichthyology 39(1): 93-102.

Albrecht MP, Ferreira MFN, Caramaschi EP (2001) Anatomical features and histology of the digestive tract of two related neotropical omnivorous fishes (Characiformes; Anastomidae). Journal of Fish Biology 58(2): 419-430. doi: 10.1111/j.10958649.2001.tb02261.x

Al-Hussaini AH (1946) The anatomy and histology of the alimentary tract of the coral feeding, Mulloides auriflamma (Forsk.) Journal of Morphology 78(1): 121-154.

AL-HussainI AH (1949) On the functional morphology of the alimentary tract of some fish in relation to differences in their feeding habits: Anatomy and histology. Quarterly Journal of Microscopical Science archives 90(2): 109-139. Angelescu V, Gneri FS (1949) Adaptaciones del aparato digestivo al regime alimentício en algunos peces del rio Uruguay y del rio de La Plata. Revista del Instituto Nacional de Investigacion de Ias Ciências Naturales 1(6): 161-281.

Arellano JM, Storch V, Sarasquete C (2002) Ultrastructural study on the intestine of Senegal sole, Solea senegalensis. Journal 
of Applied Ichthyology 18(3): 154-158. doi: 10.1046/ j.1439-0426.2002.00332.x

BARRINGTON EJW (1957) The alimentary canal and digestion, p. 109-161. In: Brown ME (Ed.) The Physiology of Fishes. New York, Academic Press.

Bértin L (1958) Appareil digestif, p. 1248-1302. In: Grassé PP (Ed.) Traité de Zoologie. Paris, Masson.

BRASIL (2013) Diretrizes da prática de eutanásia do CONCEA. Brasília, Ministério da Ciência, Tecnologia e Inovação, CONCEA, 54p.

CAO XJ, WANG WM (2009) Histology and mucin histochemistry of the digestive tract of yellow catfish, Pelteobagrus fulvidraco. Anatomia, Histologia, Embryologia 38(4): 254-261. doi: 10.1111/j.1439-0264.2009.00932.x

CINAR K, SENOL N (2006) Histological and histochemical characterization of the mucosa of the digestive tract in Flower Fish (Pseudophoxýnus antalyae). Anatomia, Histologia, Embryologia 35(3): 147-151. doi: 10.1111/j.1439-0264.2005.00629.x

Dias ACMI, Branco CWC, Lopes VG (2005) Estudo da dieta natural de peixes no reservatório de Ribeirão das Lajes, Rio de Janeiro, Brasil Lajes, Rio de Janeiro, Brasil. Acta Scientiarium Biological Sciences 27(4): 355-364.

EL BAKARY NESR (2011) Comparative scanning electron microscope study of the buccal Cavity in juvenile and adult Sea Bass (Dicentrachus labrax). World Applied Sciences Journal 12(8): 1133-1138.

Germano RM, Stabille SR, Mari Rb, Pereira JNB, Faglioni JRS, Miranda-Neto MH (2014) Morphological characteristics of the Pterodoras granulosus (Valenciennes, 1821) digestive tube (Osteichthyes, Doradidae). Acta Zoologica 95(2): 166-175. doi: 10.1111/azo.12016

GodinHo H (1967) Estudos anatômicos sobre o trato alimentar de Siluroidei Pimelodus maculatus. Revista Brasileira de Biologia 27(4): 25-33.

Godinho H, Tokimaru M, Ferri AG (1970) Histologia do trato digestivo de Pimelodus maculatus Lacépède, 1803 (Pisces, Siluroidei). Revista Brasileira de Biologia 30(4): 583-593.

Grau A, Crespo S, Sarasquete MC, González de Canales ML (1992) The digestive tract of the amberjack Seriola dumerili, Risso: a light and scanning electron microscope study. Journal of Fish Biology 41(2): 287-303.

Hernández DR, Pérez-Gianeselli M, Domitrovic HA (2009) Morphology, histology and histochemistry of the digestive system of South American Catfish (Rhamdia quelen). International Journal of Morphology 27(1): 105-111.

Horn MH (1998) Feeding and digestion, p. 43-63. In: Evans DH (Ed.) The physiology of fishes. Boca Raton, CRC Press.

Humbert W, Kirsch R, Meister MF (1984) Scanning electron microscopic study of the esophageal mucous layer in the eel, Anguilla anguilla L. Journal of Fish Biology 25(1): 117122.

Jaroszewska M, Dabrowski K, Wilczyska B, Kakareko T (2008) Structure of the gut of the racer goby Neogobius gymnotrachelus (Kessler,
1857). Journal of Fish Biology 72(7): 1773-1786. doi: 10.1111/ j.1095-8649.2008.01870.x

Kapoor BG, Smit H, Verighina IA (1975) The alimentary canal and digestion in teleosts. Advances in Marine Biology 13(C): 109-239.

Kapoor BG, Bhargava SC (1967) A study on the barbels of a marine catfish, Arius thalassinus (Rüpp.). Japanese Journal of Ichthyology 14(4): 201-206.

Khanna SS, Mehrota BK (1970) Histomorphology of the buccopharynx in relation to feeding habits in teleosts. Proceedings of the National Academy of Science India 40(B): 60-80.

Menin E, Mimura OM (1993) Anatomia comparativa do esôfago de seis peixes teleostei de água doce de distintos hábitos alimentares. Revista Ceres 40(230): 334-369.

Morrison CM, Wright JR (1999) A study of the histology of the digestive tract of the Nile tilapia. Journal of Fish Biology 54(3): 597-606.

Nikolsky GV (1963) The ecology of fishes. London, Academic Press, 352p.

Oliveira-Ribeiro CA, Fanta E (2000) Microscopic morphology and histochemistry of the digestive system of a tropical freshwater fish Trichomycterus brasiliensis (Lütken, 1874) (Siluroidei, Trichomycteridae). Revista Brasileira Zoologia 17(4): 953-971. doi: 10.1590/S0101-81752000000400007

Oliveira-Ribeiro CA, Menin E (1996) Anatomia do tubo digestivo de Trichomycterus brasiliensis (Reinhardt) e suas relações com os hábitos alimentares (Siluroidei, Trichomycteridae). Acta Biologica Paranaense 25(1): 159-171.

Park In-S, Kiм CH, ChOI JW (2012) Histological Observations and Regeneration of Barbels in Juveniles of the Chinese Longsnout Catfish Leiocassis longirostris. Fisheries and aquatic sciences 15(4): 299-303. doi: 10.5657/FAS.2012.0299

Pearse AGE (1985) Histochemistry - Theoretical and Applied. Edinburgh,Churchill Livingstone, 613p.

Petrinec Z, Nejedli S, Kuzir S, Opacak A (2005) Mucosubstances of the digestive tract mucosa in northern pike (Esox lucius L.) and european catfish (Silurus glanis L.). Veterinarski Arhiv 75(4): 317-327.

Petrini LM (1961) Sobre a presença de capilares intra-epiteliais na mucosa do estômago do cascudo (Plecostomus plecostomus Linneu). Ciências e Cultura 13: 175.

Reis RE, Kullander SO, Ferraris Jr CJ (2003) Check list of the freshwater fishes of South and Central America. Porto Alegre, EDIPUCRS, 729p.

RodRigues SS, MENIN E (2005) Anatomia da cavidade bucofaringeana de Conorhynchos conirostris (Valenciennes, 1984) (Siluriformes). Ceres 52(304): 843-862.

Rodrigues SS, Menin E (2006a) Adaptações anatômicas da cavidade bucofaringiana de Pseudoplatystoma corruscans (Spix e Agassiz, 1829) (Siluriformes, Pimelodidae) em relação ao seu hábito alimentar. Ceres 53(305): 135-146.

Rodrigues SS, Menin E (2006b) Adaptações anatômicas da cavidade bucofaringeana de Pimelodus maculatus (Lacépéde, 
1803) (Siluriformes, Pimelodidae) em relação ao seu hábito alimentar. Anais IV Congresso Ibero-americano Virtual de Aquicultura, Zaragosa, p. 133-147.

Rodrigues SS, Navarro RD, Menin E (2006) Adaptações anatômicas da cavidade bucofaringiana de Leporinus macrocephalus Garavello e Britski, 1988 (Characiformes, Anostomidae) em relação ao hábito alimentar. Biotemas 19(1): 51-58.

Santos AF, F Racca-Filho, Santos LN, Araujo FG (2009) The fish Trachelyopterus striatulus (Siluriforms: Auchenipteridae) used to sample insects in a tropical reservoir. Revista Biologia Tropical 57(4): 1081-1091.

Santos CM, Duarte S, Souza TGL, Ribeiro TP, Sales A, Araújo FG (2007) Histologia e caracterização histoquímica do tubo gastrintestinal de Pimelodus maculatus (Pimelodidae, Siluriformes) no reservatório de Funil, Rio de Janeiro, Brasil. Iheringia, Série Zoologia, 97(4): 411-417.

Schuingues CO, Lima MG, Lima AR, Martins DS, Costa GM (2013) Anatomia da cavidade bucofaringeana de Sorubim trigonocephalus (Siluriformes, Osteichthyes) Pesquisa Veterinária Brasileira
33(10): 1256-1262.

SingH CP, KAPOOR BG (1967) Histological observations on the barbels of a bagrid catfish Rita rita (Ham.). Japanese Journal of Ichthyology 14(4): 197-200.

Sis RF, Ives PJ, Jones DM, Lewis DH, Haensly WE (1979) The microscopic anatomy of the oesophagus, stomach and intestine of the channel catfish, Ictalurus punctatus. Journal of Fish Biology 14(2): 179-186.

Vegas-Velez M (1972) La structure histologique typique du tube digestif des poissons téleosteens. Tethys 4(1): 163-174.

Xiong D, Zhang L, Yu H, Xie C, Kong Y, Zeng Y, Huo B, Liu Z (2011) A study of morphology and histology of the alimentary tract of Glyptosternum maculatum (Sisoridae, Siluriformes). Acta Zoologica 92 (2): 161-169. doi: 10.1111/ j.1463-6395.2010.00458.x

Yashpal M, MitTal AK (2014) Serous goblet cells: The protein secreting cells in the oral cavity of a catfish, Rita rita (Hamilton, 1822) (Bagridae, Siluriformes). Tissue Cell 46(1): 09-14. doi: 10.1016/j.tice.2013.08.001

Submitted: 22 March 2015

Received in revised form: 8 June 2015

Accepted: 19 June 2015

Editorial responsibility: Carolina Arruda Freire 